\title{
Islamic Banks vs. Conventional Banks in Bangladesh: A Comparative Study Based on its Efficiency in Operation
}

\author{
Faisal Ahmad \\ MPhil Student \\ Department of Islamic Studies \\ University of Dhaka, Bangladesh \\ E-mail: 2dr.faisal@gmail.com
}

\begin{abstract}
The main purpose of this study is to make a comparison between Islamic banks (IBs) and Conventional banks (CBs) in Bangladesh based on its efficiency in operation. The Data Envelopment Analysis (DEA) is employed under CRS and VRS approach, which allows for the decomposition of efficiency into technical, allocated and cost efficiency. The study also meas ures changes in productivity over the time as a result of technical progress by employing the Malmquist Total Factor Productivity Index. The results explain that the technical efficiency of IBs is better than that of CBs, but allocated and cost efficiency (CE) of IBs are higher than CBs. In Bangladesh there are 62 commercial banks included 8 Islamic Banks that are regulated by Bangladesh Bank (BB).
\end{abstract}

\section{Keywords: Islamic Banks, Conventional Banks, Data Envelopment Analysis, Islamic Banking Industry.}

\section{Introduction}

The importance of financial sector for the growth of an economy is obvious and cannot be overemphasized. Economic growth and development is possible if financial sector works efficiently and banks being part of financial sector work actively when they utilize their available resources at optimal levels (Shahid et al. 2010). In Bangladesh there are two kinds of banking system: CBs and IBs which are allowed by the Bangladesh Bank (BB) to provide Islamic banking products and services.

The concept of Islamic banking system provides an interesting ground to compare the efficiency of commercial banks in different countries of the world such as Malaysia, Sudan, UAE etc. (Sufian, 2007b). This paper is an empirical investigation to examine the efficiency of Islamic banking vs. commercial banking in Bangladesh.

The Islamic banking industry (IBI) in Bangladesh had grown from I983 to a cumulative branch network of approximately 350 branches and 62I ATM Booths by Dec, 2019 (BB), covering all the major cities of the country. One of the key reasons of this impressive advancement in IBI is friendly policies by the BB. The share of IBI in the banking system in Bangladesh was raised to $10 \%$ in 2019 from just $0.5 \%$ in 2003 and it was much higher growth, on an annualized basis, than that of the other Muslim economies (Figure-I). Now BB has planned to enhance the market share of IBI up to $24 \%$ of overall banking industry by 2019 in terms of deposits, assets and lending.

Many researchers extensively conducted their studies on the efficiency and performance of Islamic and conventional banking systems and made a comparative analysis of different countries like Saudi Arabia (Al-Faraj et al., I993) Bangladesh (Sarker, 1999).

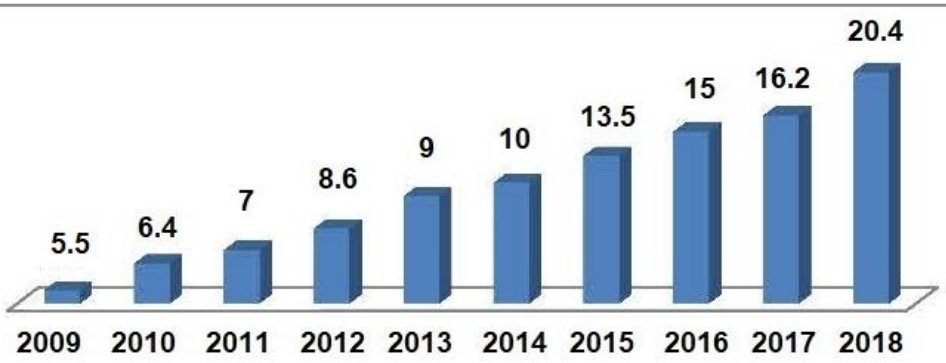

Figure-1. Market share of IBI in the overall banking system of Bangladesh (\%) 


\section{Literature Review}

Moin \& Chen (2008) analyzed the performance of Islamic Bank and eight CBs of Bangladesh using ratio analysis for the period 2007-2019 and described that Islamic banking was a fastest growing market but had different challenges to face.

They observed that Islamic Bank was less profitable (less efficient) and more solvent. In another study, Ellahi et al. (2009) concluded that Islamic banks in Bangladesh were less efficient technically and costly as compare to CBs during the period of 2004-08. These results were partially confirmed by Moin (2013) who compared the performance of Islamic Banks in Bangladesh with eight Bangladeshi CBs and evaluated the performance of the banks in profitability, liquidity, risk and solvency, and efficiency for the period 2003-2007 using the ratio analysis. He found that IBs was less profitable, more solvent, and also less efficient comparing to the average of the eight CBs but it was improving significantly over the time representing convergence with the performance of the CBs.

All above studies focused efficiency comparison between IBI and conventional banking industry in specific region or country or period. Though there are some studies on efficiency comparison between both types of banking in Bangladesh, but studies used the sample which was limited to one or two Islamic banks which do not represent the whole IBI and compared with the sample of conventional banking as well as interest base banking operations. The present study includes eight Islamic banks compare to eight conventional banks of Bangladesh and the findings of this study will fill the gap in literature.

\section{Objectives of the Research}

The main objectives of this study are to investigate:

- Which system Islamic banking or CBs is technically efficient?

- Which system: Islamic banking or CBs is cost efficient?

- Which system: Islamic banking or CBs has a higher allocated efficiency?

\section{Overview on Islamic Bank vs. Conventional Banks}

\section{I What is Islamic Banking?}

Islamic banking, also known as non-interest banking, is a banking system that is based on the principles of Islamic or Sharia law and guided by Islamic economics. Two fundamental principles of Islamic banking are the sharing of profit and loss, and the prohibition of the collection and payment of interest by lenders and investors. Islamic law prohibits collecting interest or "riba."

\subsection{Principles of Islamic Banking}

The principles of Islamic banking follow Sharia law, which is based on the Quran and the Hadith, the recorded sayings, and actions of the Prophet Muhammad. When more information or guidance is necessary, Islamic bankers turn to learned scholars or use independent reasoning based on scholarship and customs. The bankers also ensure their ideas do not deviate from the fundamental principles of the Quran.

\subsection{What is a Conventional Bank?}

Conventional banks are known as commercial banks, which are profit-making organizations that generally aren't based on religious principles. That said, earning money is also a primary function of an Islamic commercial bank.

\subsection{Basic Principles that Commercial Banks Follow}

- Commercial banks follow certain principles which are very important for banks to remain in the competition in modem days.

- The bank which deals with money and money worth to earn prom is known as the commercial bank.

- Commercial banks must maintain some principles which are very important for banks to remain in the competition in modem days.

\subsection{Difference between Islamic Banking and Conventional Banking}

Let us first understand the major difference between Islamic banking and conventional banking system. "Islamic banking is an Ethical Banking System, and its practices are based on Islamic (Shariah) laws. On the other hand, Conventional Banking is an Un-Ethical Banking system based on Man-Made Laws. It is profit-oriented and its purpose is to make money through interest”.

\begin{tabular}{ll}
\hline \multicolumn{1}{c}{ Conventional Banking System } & \multicolumn{1}{c}{ Islamic Banking System } \\
\hline $\begin{array}{l}\text { Money is a product besides medium of exchange and store of } \\
\text { value }\end{array}$ & Real Asset is a product. Money is just a medium of exchange \\
\hline Time value is the basis for charging interest on capital & $\begin{array}{l}\text { Profit on exchange of goods \& services is the basis for earning } \\
\text { profit }\end{array}$ \\
\hline
\end{tabular}




\begin{tabular}{|c|c|}
\hline $\begin{array}{l}\text { Interest is charged even in case, the organization suffers losses. } \\
\text { Thus no concept of sharing loss }\end{array}$ & Loss is \\
\hline $\begin{array}{l}\text { While disbursing cash finance, running finance or working capital } \\
\text { finance, no agreement for exchange of goods } \& \text { services is made }\end{array}$ & $\begin{array}{l}\text { The execution of agreements for the exchange of goods \& } \\
\text { services is must, while disbursing funds under Murabaha, } \\
\text { Salam \& Istisna contracts }\end{array}$ \\
\hline $\begin{array}{l}\text { Due to nonexistence of goods } \& \text { services behind the money while } \\
\text { disbursing funds, the expansion of money takes place, which } \\
\text { creates inflation }\end{array}$ & $\begin{array}{l}\text { Due to existence of goods \& services no expansion of money } \\
\text { takes place and thus no inflation is created }\end{array}$ \\
\hline $\begin{array}{l}\text { Due to inflation the entrepreneur increases prices of his goods \& } \\
\text { services, due to incorporating inflationary effect into cost of } \\
\text { product }\end{array}$ & $\begin{array}{l}\text { Due to control over inflation, no extra price is charged by the } \\
\text { entrepreneur }\end{array}$ \\
\hline $\begin{array}{l}\text { Real growth of wealth does not take place, as the money remains } \\
\text { in few hands }\end{array}$ & $\begin{array}{l}\text { Real growth in the wealth of the people of the society takes } \\
\text { place, due to multiplier effect and real wealth goes into the } \\
\text { ownership of lot of hands }\end{array}$ \\
\hline $\begin{array}{l}\text { Debts financing gets the advantage of leverage for an enterprise, } \\
\text { due to interest expense as deductible item form taxable profits. } \\
\text { This causes huge burden of taxes on salaried persons. Thus the } \\
\text { saving and disposable income of the people is affected badly. This } \\
\text { results decrease in the real gross domestic product }\end{array}$ & $\begin{array}{l}\text { Sharing profits in case of Mudarabah and sharing in the } \\
\text { organization of business venture in case of Musharakah, } \\
\text { provides extra tax to Federal Government. This leads to } \\
\text { minimize the tax burden over salaried persons. Due to which } \\
\text { savings \& disposable income of the people is increased, which } \\
\text { results the increase in the real gross domestic product }\end{array}$ \\
\hline
\end{tabular}

\section{Methodology and Model Specification \\ 5.I Efficiency Measurement}

Banking efficiency can be measured in two ways either by using traditional financial ratio analysis (FRA) or by the distance function approach. Financial ratios analysis is a popular method and many researchers used it quite extensively to evaluate the bank performance as calculation and interpretation is easy (Hassan \& Bashir, 2003). It is easy to compare the performance of a bank with different other banks and with benchmark (Halkos \& Salamouris, 2004). But it was also found that the evaluation of the bank performance by financial ratios was improper because banks were large and one ratio cannot sketch a picture of performance of complex organizations (Ho \& Zhu, 2004). According to Shahid et al. (2010) FRA measures the performance in short run and does not incorporate the management decisions and actions regarding investment that may affect in future. So this study used the distance function approach which is the best method for efficiency analysis.

\subsection{Data Envelopment Analysis (DEA)}

Charnes et al. (1978) introduced the term Data Envelopment Analysis (DEA) first time in 1978. The DEA is a linear programming technique that evaluates relative efficiency and performance of organizations where multiple inputs and outputs complicate the efficiency comparison (Hassan, 2005). Literature shows four dominate approaches: the operating approach, the production approach, the intermediation approach and the revenue approach.

The operating approach which is income based approach considers the banks as business entities having objective to earn maximum revenue by the minimum cost for running the business (Leightner \& Lovell, 1998). Under this approach, total revenue is output while inputs are total expenses. This approach considers the perspective of cost/revenue management. The operating approach has been popular for defining inputs and outputs of banks (Jemric \& Vujcic, 2002).

The production approach is used to measure the efficiency of bank branches (Berger \& Humphrey, 1992). Applying this approach, financial firms are considered as producer of services for customers as customer avail different services through depositing money or borrowing. So under this approach number of accounts and transactions are used to measure output and inputs are physical capital and the number of employees. Many researchers used this approach as Ferrier \& Lovell (1990), Sufian, (2007a).

In DEA the efficiency score of a specific firm is not measured by an absolute form but is relative to the other firms under consideration. DEA determines the efficiency of firm through production possibility frontier. Firm is supposed to be efficient; if it operates on DEA frontier otherwise it would be considered inefficient. 


\subsection{Malmquist Index of Profitability Change}

DEA also estimate Total Factor Productivity (TFP) change of the panel data. This Index measures the TFP change between two data points by calculating the ratio of the distances between each data point relative to a common technology. According to Fare et al., specification of Malmquist productivity change is expressed as a geometric mean of two Malmquist indices as given in the following equation:

$$
\mathrm{m}_{0}\left(\mathrm{y}_{\mathrm{t}+1}, \mathrm{x}_{\mathrm{t}+1}, \mathrm{y}_{\mathrm{t}}, \mathrm{x}_{\mathrm{t}}\right)=\left[\frac{d_{0}^{t} x_{t+1}, y_{t+1}}{d_{0\left(x_{t}, y_{t}\right)}^{t}} \times \frac{d_{0}^{t+1} x_{t+1}, y_{t+1}}{d_{0\left(x_{t}, y_{t}\right)}^{t+1}}\right]^{1 / 2}
$$

This equation is productivity index which is the geometric mean of a pair of ratios of output distance function. The performance of the data is compared in first ratio from period $t$ to $t+I$ relative to production possibilities existing in period $\mathrm{t}$, while second ratio compares the performance of the same data relative to production possibilities existing in period $t+I$. Here $d o$ is the distance from the frontier. If its value is greater than one then it will specify positive TFP growth during period $t$ to period $t+I$.

\section{Data and Inputs-Outputs}

6.I Data

Specifically, this study compares efficiency of eight Islamic banks with eight CBs in Bangladesh. Annual data is compiled from the income statements, balance sheets and the publications that are issued by $\mathrm{BB}$.

\subsection{Inputs-Outputs}

The present study focuses intermediation approach based on practical and theoretical considerations to evaluate and compare the efficiency of banks. The study uses deposits $\left(\mathrm{X}_{1}\right)$, fixed assets $\left(\mathrm{X}_{2}\right)$ and labor $\left(\mathrm{X}_{3}\right)$, as inputs while the investment portfolio (yI) and Loans $\&$ advances (y2) are characterized as outputs.

The selection of variables (inputs and outputs) for the DEA model is influenced by different reasons such as previous literature with these variables is available on banking sector with small sample. But this study will take eight Islamic banks and eight CBs for the period of 2013-2018. Deposits (saving accounts, current accounts and money market accounts) are one of the main inputs of the study and define as all available resources to the banks for carrying out their operations like lending and investments.

Islamic banks do not enter into loan contracts as CBs. So advances of Islamic banks are used as proxy of "loan \& advances" ( $\mathrm{L} \& \mathrm{~A}$ ). CBs make profit from the difference between lending and borrowing interest rates. Islamic banks earn profit from the difference between the entrepreneurs and the depositors profit ratios.

Table I. List of financial institutions and Inputs-outputs used in study

\begin{tabular}{|c|c|c|c|c|}
\hline No. & Islamic Banks & Conventional Banks & Input & Output \\
\hline $\bar{I}$ & Islamic Bank Bangladesh Ltd. & AB Bank Limited & \multirow{4}{*}{ Deposit- XI } & \multirow{2}{*}{$\mathrm{IP}(y \mathrm{I})$} \\
\hline 2 & ICB Islamic Bank & Bank Asia Limited & & \\
\hline 3 & Shahjalal Islami Bank & BRAC Bank Limited & & $L \& A(y 2)$ \\
\hline 4 & First Security Islami Bank Limited & City Bank Limited & & \\
\hline 5 & Al-Arafah Islami Bank Limited & Dhaka Bank Limited & Labour - X 3 & \\
\hline
\end{tabular}

\section{Empirical Findings}

\section{I DEA Efficiency Results}

The technical efficiency (TE) determines the scale to which the bank can reduce its input to produce the specified output. The value of TE being 'I' show that the industry is efficient and is working on the production possibility frontier (PPF). And the value less thanI means that the industry is wasting its resources and performing bellows the PPF.

At first, I calculated and examined the efficiencies (TE, CE and AE) of IBs and CBs operating cost in Bangladesh applying the DEA method for each year using Constant Return to Scale (CRS) and Variable Return to Scale (VRS) models. But efficiency values under VRS were better than the values under CRS for Islamic banks. The mean efficiency scores of IBs and CBs for each year have been calculated under the assumption of CRS and VRS. Now, analysis has been presented in table-2 and 3 .

Table-2 shows the results during the period of study, under VRS assumption it was found that the Islamic banks displayed mean TE of $97.5 \%$, suggesting mean input waste of $2.5 \%$. In other words, the Islamic banks could produce the same 
amount of outputs by only using $97.5 \%$ of the amount of inputs it currently uses, while mean of TE of CBs was I00\% during the last 6 years. During the period of study, our results suggested that CBs were technically stronger (Figure-2 and 3). Islamic banks outperformed the CBs by $9 \%$ and $5 \%$ in mean values of TE and CE respectively during the studied period. Mean of $\mathrm{AE}$ of Islamic banks and CBs was $97.5 \%$ and $88.5 \%$ respectively, and mean of Cost efficiency of Islamic banks and CBs was $94.9 \%$ and $88.5 \%$ respectively (Table- 2 ).

Table 2. Efficiency Summary of IBs and CBs under VRS

\begin{tabular}{|c|c|c|c|c|c|}
\hline \multirow[t]{2}{*}{ Bank Type } & \multirow[t]{2}{*}{ No of banks } & \multirow[t]{2}{*}{ Years } & \multicolumn{3}{|c|}{ Mean } \\
\hline & & & $\overline{\mathrm{TE}}$ & $\overline{\mathrm{AE}}$ & $\overline{C E}$ \\
\hline \multirow[t]{7}{*}{ Islamic Banks } & 8 & 2013 & 0.988 & 0.982 & 0.971 \\
\hline & 8 & 2014 & 1.000 & 0.995 & 0.995 \\
\hline & 8 & 2015 & 0.986 & $0.97 \mathrm{I}$ & 0.958 \\
\hline & 8 & 2016 & 0.988 & 0.995 & 0.983 \\
\hline & 8 & 2017 & 0.900 & 0.997 & 0.898 \\
\hline & 8 & 2018 & 0.979 & 0.914 & 0.894 \\
\hline & Overall Mean & & 0.973 & 0.975 & 0.949 \\
\hline \multirow[t]{7}{*}{ Conventional banks } & 8 & 2013 & 1.000 & 0.834 & 0.834 \\
\hline & 8 & 2014 & 1.000 & 0.799 & 0.799 \\
\hline & 8 & 2015 & 1.000 & 0.908 & 0.908 \\
\hline & 8 & 2016 & 1.000 & 0.896 & 0.896 \\
\hline & 8 & 2017 & 1.000 & 0.920 & 0.920 \\
\hline & 8 & 2018 & 1.000 & 0.955 & 0.955 \\
\hline & Overall Mean & & 1.000 & 0.885 & 0.885 \\
\hline
\end{tabular}

Note: $\mathrm{TE}=$ Technical efficiency, $\mathrm{AE}=$ allocative efficiency, $\mathrm{CE}=$ cost efficiency

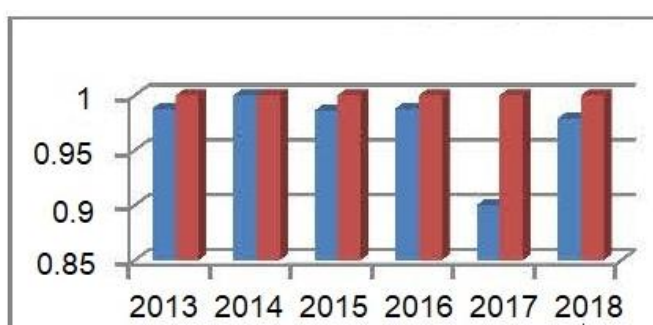

Figure-2. TE under VRS

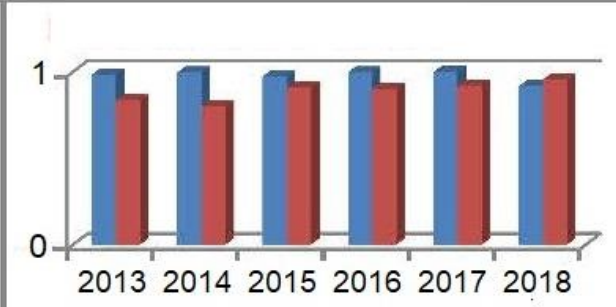

Figure-3. AE under VRS
IBs

CBs

Table-3 reports the sample statistics of the various mean efficiency scores of Islamic banks and CBs for the years 2013-18 under CRS. For the last six years, mean of TE of Islamic banks is ranging from $88.6 \%$ to $97.5 \%$, which indicates that Islamic banks were utilizing $98.3 \%$ of their input resources till December 2018 and it is the sign that Islamic banks are growing and showing a good progress in the financial market of Bangladesh. But the mean of TE of CBs was ranging from $100 \%$ to $94.5 \%$ which is much higher than that of Islamic banks (Figure-4 and 5). However, if we consider the growth ratios, we will found that there was marginal decline of $5 \%$ in mean of TE in case of CBs, while mean of TE of Islamic banks grew $10 \%$ over the same period. Though during the period, there was a bit decline of $1 \%$ in mean of TE of Islamic banks in 2015, but it is ignorable. With overall mean of TE, Islamic banks and CBs showed $98.3 \%$ and 100\% respectively (Table$3)$.

Table 3. Efficiency Summary of IBs and CBs under CRS

\begin{tabular}{cccccc}
\hline Bank Type & \multicolumn{2}{c}{ No of banks } & Years & \multicolumn{3}{c}{ Mean } \\
\cline { 3 - 6 } & & & TE & $\mathrm{AE}$ & $\mathrm{CE}$ \\
\hline Islamic Banks & 8 & 2013 & 0.886 & 0.810 & 0.700 \\
\cline { 2 - 6 } & 8 & 2014 & 0.983 & 0.769 & 0.757 \\
\hline
\end{tabular}




\begin{tabular}{cccccc}
\hline & 8 & 2015 & 0.977 & 0.847 & 0.829 \\
\cline { 2 - 6 } & 8 & 2016 & 0.988 & 0.993 & $0.98 \mathrm{I}$ \\
\cline { 2 - 6 } & 8 & 2017 & 0.883 & 0.955 & 0.840 \\
\cline { 2 - 6 } & 8 & 2018 & 0.975 & 0.902 & 0.879 \\
\hline Conventional banks & Overall Mean & & 0.949 & 0.879 & $0.83 \mathrm{I}$ \\
\cline { 2 - 6 } & 8 & 2013 & 1.000 & 0.528 & 0.528 \\
\cline { 2 - 6 } & 8 & 2014 & 1.000 & 0.320 & 0.320 \\
\cline { 2 - 6 } & 8 & 2015 & 1.000 & 0.514 & 0.514 \\
\cline { 2 - 6 } & 8 & 2016 & 0.978 & 0.838 & 0.824 \\
\cline { 2 - 6 } & 8 & 2017 & 0.996 & 0.809 & 0.806 \\
\hline
\end{tabular}

Note: $\mathrm{TE}=$ Technical efficiency, $\mathrm{AE}=$ allocative efficiency, $\mathrm{CE}=$ cost efficiency

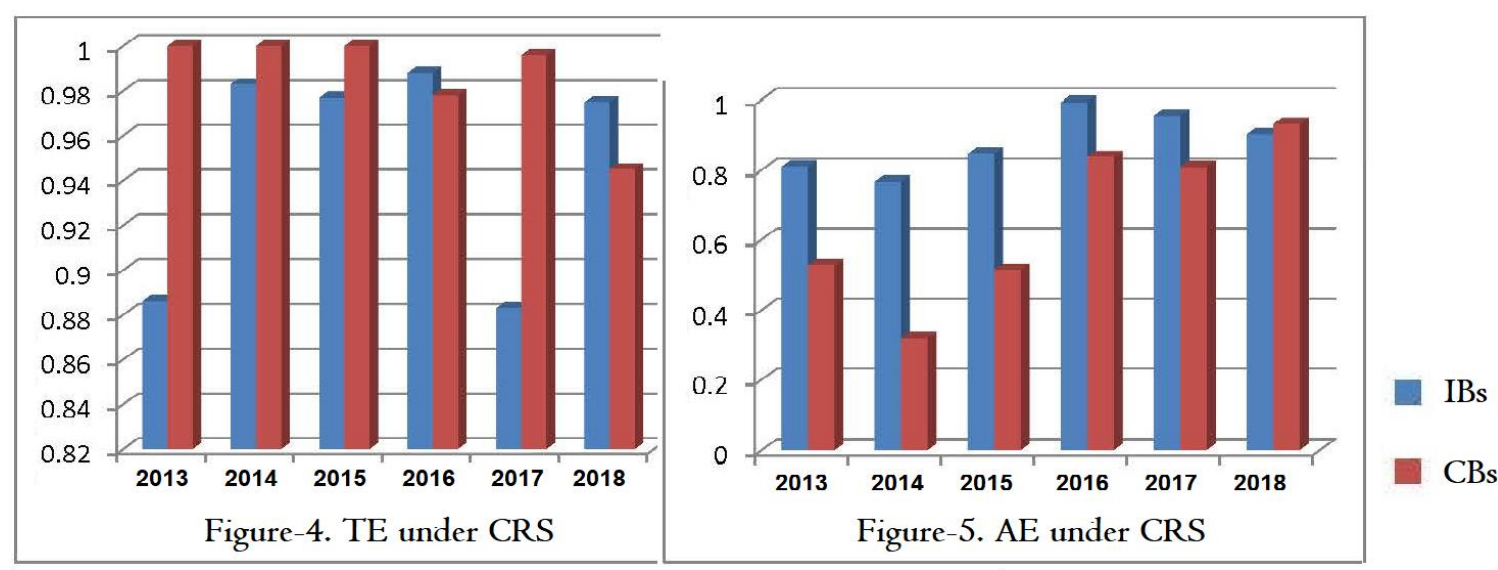

Now looking at the cost efficiency of the Islamic banks, I came to know that mean of CE of Islamic banks is ranging from $70 \%$ to $88 \%$, while mean of CE of CBs is ranging from $52 \%$ to $88 \%$ which is not bad in comparison with Islamic banks. But if we consider overall mean of CE, we will found that Islamic banks having $83 \%$ CE is more cost efficient as compared to conventional banking having 64\% CE. Mean of AE of Islamic banks and CBs are $87.9 \%$ and $65.7 \%$ respectively under CRS approach. Islamic banks are performing better in $\mathrm{AE}$ and $\mathrm{CE}$ but need enhancement in their TE.

Table 4. Depositors of IBs and CBs from 2000 to 2015

\begin{tabular}{cccc}
\hline Year \& Percentage (\%) & CBs & IBs & Total \\
\hline 2000 & 27530868 & I384152 & 28915020 \\
\hline$\%$ & 95.21 & 4.79 & 100 \\
\hline 2005 & 29894916 & 3192755 & 33087671 \\
\hline$\%$ & 90.35 & 9.65 & 100 \\
\hline 2010 & 42185797 & 6493140 & 48678937 \\
\hline$\%$ & 86.66 & 13.34 & 100 \\
\hline 2015 & 62443196 & 13780268 & 76223464 \\
\hline$\%$ & 81.92 & 18.08 & 100 \\
\hline & Source: Bangladesh Bank report
\end{tabular}

Table 5. Deposit and Loan of IBs and CBs as on June 2019

\begin{tabular}{ccccc}
\hline Details & Unit & CBs & IBs & Total \\
\hline Depositor & Number & 82305272 & I803I924 & I00337I96 \\
\cline { 2 - 5 } & $\%$ & 82.03 & I7.97 \\
\hline
\end{tabular}




\begin{tabular}{ccccc}
\hline \multirow{2}{*}{ Deposit } & Cr Tk & 914135 & 225696 & I I3983I \\
\cline { 2 - 5 } & $\%$ & 80.20 & 19.80 & 100 \\
\hline \multirow{2}{*}{ Borrower } & Number & 9168180 & 1487279 & 10655459 \\
\cline { 2 - 5 } & $\%$ & 86.04 & 13.96 & 100 \\
\hline \multirow{2}{*}{ Loan } & $\mathrm{Cr} T \mathrm{~T}$ & 729100 & 222347 & $95 \mathrm{I} 447$ \\
\cline { 2 - 5 } & $\%$ & 76.63 & 23.37 & 100 \\
\hline
\end{tabular}

Source: Bangladesh Bank report

Islamic Banking in Bangladesh as of 2019 by the number

- Total deposit: Tk 280,228cr

- Total investments: Tk 262,752cr

- Both of which are about $25 \%$ of the banking sector

- Excess liquidity: Tk 9,733cr

(Which is about $9.2 \%$ of the banking sector)

- Total number of branches: 1380

- Total manpower: 35,906

Source: Daily Star newspaper, Bangladesh (Uddin, 2020).

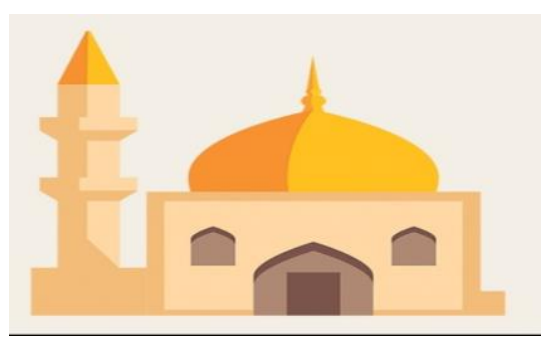

\subsection{Malmquist Index of Profitability Change}

This index provides a change in TFP for the banks during the specified period. TFP is further decomposed into different components. If the value of the Index (or any of its components) exceeds I then it indicates improvements in the efficiency during the period and if the value is less than I then it infers reduction in TFP.

Table-5 presents the Islamic banks' total productivity change annually for 2015-18. It shows that mean value of TFP is 1.053 , which is greater than I indicating that banks had growth rate of $5.3 \%$ during the 6 years. Growth in TFP is high relative to the growth in efficiency, technical efficiency, pure technical efficiency and scale efficiency which is $2.4 \%, 2.8 \%, 1.0 \%$ and $1.4 \%$ respectively.

Table 5. Malmquist Index summary of IBs

\begin{tabular}{cccccc}
\hline Year & Effch & Techch & Pech & Sech & Tfpch \\
\hline 2014 & I.407 & 0.322 & I.059 & I.329 & 0.452 \\
\hline 2015 & 0.915 & 3.238 & 0.912 & 1.003 & 2.962 \\
\hline 2016 & I.II2 & $0.92 \mathrm{I}$ & $\mathrm{I} .015$ & 1.096 & 1.025 \\
\hline 2017 & 0.945 & 2.300 & 1.047 & 0.902 & 2.173 \\
\hline 2018 & 0.834 & 0.520 & 1.025 & 0.814 & 0.434 \\
\hline Mean & I.024 & I.028 & I.010 & I.014 & I.053 \\
\hline
\end{tabular}

Note: Effch=efficiency change, Techch=technical efficiency change, Pech=Pure technical efficiency change,

Sech=Scale efficiency change and $T f p c h=$ total factor profitability change

For CBs, Table-6 represents the summary and indicates that there is a drastic decline in total factor profitability by $5.7 \%$ over the period. But there is growth in efficiency and scale efficiency by $0.4 \%$ and $1.4 \%$ respectively. Technical efficiency\& $d$ pure technical efficiency reduced by $6.1 \% \& I \%$.

Table 6. Malmquist Index summary of CBs

\begin{tabular}{cccccc}
\hline Year & Effch & Techch & Pech & Sech & Tfpch \\
\hline 2015 & 0.717 & 1.800 & 0.928 & 0.773 & 1.290 \\
\hline 2016 & 1.619 & 0.247 & 1.106 & 1.463 & 0.400 \\
\hline 2017 & 0.620 & 2.650 & 0.871 & 0.712 & 1.642 \\
\hline 2018 & 1.415 & 0.659 & 1.075 & 1.316 & 0.932 \\
\hline Mean & I.004 & 0.939 & 0.990 & I.014 & 0.943 \\
\hline
\end{tabular}

Note: Effch=efficiency change, Techch=technical efficiency change, Pech=Pure technical efficiency change,

Sech=Scale efficiency change and $T$ fpch $=$ total factor profitability change 


\section{Future Research}

The future recommendation of this paper is that it can be extended to consider other approaches as the production and revenue approach along with the intimidation approach, which has been applied in this paper. It is also suggested that further analysis for investigation of Islamic banks and CBs efficiency could be undertaken by considering the risk exposure factors.

\section{Conclusion}

This study concludes that overall mean of TE for CBs under both VRS \& CRS modes is higher than that of Islamic Banks. Findings also suggest that Islamic banks have exhibited higher $\mathrm{CE}$ and $\mathrm{AE}$ values which mean that Islamic banking is producing services at less cost and also taking into account customer's preferences. This is one of the best signs for economy that Islamic banks are on the horizon of improving their efficiency and are performing better than CBs. Malmquist Total Factor Productivity Index also shows positive growth in productivity over time for Islamic banks, while it shows negative growth for CBs.

There may be different reasons for the relatively better performance of Islamic banks. One reason may be that Islamic banks are fully focused on the interest free direction that keeps the industry more efficient, but CBs are working in both directions interest base and interest free which make their customers to be confused and hesitated to continue with them. On the other hand, equity based investment is also an important factor of good performance of Islamic banks. The findings also show that during financial crisis Islamic banks are capable to attract institutions, investors and people. In such circumstances BB's friendly policies for Islamic banks play vital roles in growing Islamic banking industry in Bangladesh-economy.

\section{References}

Al-Faraj, T. N., Alidi, A. S., \& Bu-Bshait, K. A. (I993). Evaluation of bank branches by means of data envelopment analysis. International Journal of Operations \& Production Management.

Bangladesh Bank Annual Report. Retrieved from https://www.bb.org.bd/pub/publictn.php

Berger, A. N., \& Humphrey, D. B. (I992). Measurement and efficiency issues in commercial banking. In Output measurement in the service sectors (pp. 245-300). University of Chicago Press.

Charnes, A., Cooper, W. W., \& Rhodes, E. (1978). Measuring the efficiency of decision making units. European journal of operational research, 2(6), 429-444.

Ellahi, N., Khattak, N., Rehman, K., \& Jamil. (2009). Testing Technical and Cost Efficiency of Bangladeshi Islamic Banking System. 8th International Conference on Islamic Economics and Finance.I-IO.

Ferrier, G. D., \& Lovell, C. K. (1990). Measuring cost efficiency in banking: Econometric and linear programming evidence. Journal of econometrics, 46(I-2), 229-245.

Halkos, G. E., \& Salamouris, D. S. (2004). Efficiency measurement of the Greek commercial banks with the use of financial ratios: a data envelopment analysis approach. Management accounting research, I5(2), 20I-224.

Hassan, M. K. (2005, December). The cost, profit and X-efficiency of Islamic banks. In I2th ERF Annual Conference, I9th2Ist December, Egypt.

Hassan, M. K., \& Bashir, A. H. M. (2003, December). Determinants of Islamic banking profitability. In IOth ERF annual conference, Morocco (Vol. 7, pp. 2-3I).

Ho, C. T., \& Zhu, D. S. (2004). Performance measurement of Taiwan's commercial banks. International Journal of Productivity and Performance Management.

Jemric, I., \& Vujcic, B. (2002). Efficiency of banks in Croatia: A DEA approach. Comparative Economic Studies, 44(2-3), I69193.

Leightner, J. E., \& Lovell, C. K. (I998). The impact of financial liberalization on the performance of Thai banks. Journal of economics and business, 50(2), II5-I3I.

Moin, M. S., \& Chen, Y. (2008), "Performance of Islamic banking and conventional Banking in Bangladesh: a comparative study”. University of Skovde: School of Technology and Society.

Moin, M. S. (2013). Financial Performance of Islamic Banking and Conventional Banking in Bangladesh: A Comparative Study, International Journal of Innovative and Applied Finance.

Sarker, M. A. A. (1999). Islamic banking in Bangladesh: performance, problems, and prospects. International Journal of Islamic Financial Services, I(3), I5-36.

Shahid, H., Rehman, R.U., Niazi, G.S.K., \& Raoof. A. (2010). Efficiencies Comparison of Islamic and Conventional Banks of Pakistan ." International Research Journal of Finance and Economics,49, 24-42.

Sufian, F. (2007a). Trends in the efficiency of Singapore's commercial banking groups. International Journal of Productivity and Performance Management.

Sufian, F. (2007b). The efficiency of Islamic banking industry in Malaysia: Foreign vs domestic banks. Humanomics: The International Journal of Systems and Ethics, 23(3), I74-I92. 
Uddin, AKM Z. (2020). The curious rise of Islamic banking in Bangladesh. Daily Star News Paper, Bangladesh. Retrieved from https://www.thedailystar.net/business/news/the-curious-rise-islamic-banking-bangladesh-I 880035.

\section{Copyrights}

Copyright for this article is retained by the author(s), with first publication rights granted to the journal. This is an open-access article distributed under the terms and conditions of the Creative Commons Attribution license (http://creativecommons.org/licenses/by/4.0/). 